Deviant Conduct in World Politics 
Also by Deon Geldenhuys

FOREIGN POLITICAL ENGAGEMENT: REMAKING STATES IN THE POST-COLD WAR WORLD

ISOLATED STATES: A COMPARATIVE ANALYSIS

THE DIPLOMACY OF ISOLATION: SOUTH AFRICAN FOREIGN POLICY MAKING

(WRITING AS TOM BARNARD): SOUTH AFRICA 1994-2004: A POPULAR HISTORY 


\section{Deviant Conduct in World Politics}

Deon Geldenhuys

Professor of Politics, Rand Afrikaans University,

Johannesburg, South Africa

palgrave 
(C) Deon Geldenhuys 2004

All rights reserved. No reproduction, copy or transmission of this publication may be made without written permission.

No paragraph of this publication may be reproduced, copied or transmitted save with written permission or in accordance with the provisions of the Copyright, Designs and Patents Act 1988, or under the terms of any licence permitting limited copying issued by the Copyright Licensing Agency, 90 Tottenham Court Road, London W1T 4LP.

Any person who does any unauthorized act in relation to this publication may be liable to criminal prosecution and civil claims for damages.

The author has asserted his right to be identified as the author of this work in accordance with the Copyright, Designs and Patents Act 1988.

First published 2004 by

PALGRAVE MACMILLAN

Houndmills, Basingstoke, Hampshire RG21 6XS and

175 Fifth Avenue, New York, N. Y. 10010

Companies and representatives throughout the world

PALGRAVE MACMILLAN is the global academic imprint of the Palgrave

Macmillan division of St. Martin's Press, LLC and of Palgrave Macmillan Ltd. Macmillan ${ }^{\circledR}$ is a registered trademark in the United States, United Kingdom and other countries. Palgrave is a registered trademark in the European Union and other countries.

ISBN 978-1-349-51609-4 ISBN 978-0-230-00071-1 (eBook)

DOI $10.1057 / 9780230000711$

This book is printed on paper suitable for recycling and made from fully managed and sustained forest sources.

A catalogue record for this book is available from the British Library.

Library of Congress Cataloging-in-Publication Data

Geldenhuys, Deon.

Deviant conduct in world politics/ Deon Geldenhuys.

p. $\mathrm{cm}$.

Includes bibliographical references and index.

ISBN 978-1-349-51609-4

1. World politics-1989-2. Terrorism. 3. Belligerency. 4. Terrorism. 5. Intervention (International law) I. Title.

D860.G485 2004

909.83-dc22

2003066189 


\section{Contents}

Acknowledgements viii

Introduction ix

1 Pariahs, Outcasts and Rogues: the Limitations of 1

Popular Labels

Pariahs and outcasts 1

Meanings of the term 'rogue'

The rise of rogue states 4

Implications of America's rogue state policy $\quad 6$

Bush II: confronting the axis of evil 9

Conclusion 11

2 Deviant Actors in World Politics: an Analytical Framework 13

Theories of deviance 13

The meaning of international norms 17

Deviant states and international order $\quad 22$

Sins of contemporary deviant states $\quad 23$

Non-state deviance $\quad 37$

External actors: defending international norms 40

Ends and means in anti-deviant actions $\quad 41$

A typology of deviants $\quad 46$

Deviant responses to external pressure $\quad 47$

In lieu of a conclusion $\quad 50$

3 From Turkey to Rhodesia: an Assortment of Outcasts 51

Ottoman Empire $\quad 52$

Bolshevik Russia $\quad 53$

Weimar Germany $\quad 55$

Fascist Italy $\quad 56$

Francoist Spain $\quad 57$

Salazarist Portugal $\quad 59$

People's Republic of China $\quad 61$

German Democratic Republic 63

Rhodesia 64

Conclusion 66

4 Principal Pariahs of the Cold War Era 68

Republic of China $\quad 68$

$\begin{array}{ll}\text { Israel } & 70\end{array}$

$\begin{array}{ll}\text { Chile } & 76\end{array}$ 
vi Contents

$\begin{array}{ll}\text { South Africa } & 79\end{array}$

Conclusion $\quad 83$

5 Iraq $\quad 85$

From empire to imperial ambitions $\quad 85$

Labelling the deviant $\quad 90$

Iraq's transgressions $\quad 91$

International demands and objectives $\quad 98$

Foreign action against Iraq 101

Iraq's reactions to external pressure 109

$\begin{array}{ll}\text { Conclusion } & 110\end{array}$

6 Iran 112

From king of kings to mullah of all Muslims 112

Naming the deviants $\quad 118$

Iran's transgressions $\quad 119$

Foreign demands $\quad 129$

External responses to Iran's deviant conduct 132

Iran's reactions to foreign pressure 138

$\begin{array}{ll}\text { Conclusion } & 140\end{array}$

7 Libya 142

Libya's road from obscurity to notoriety 142

$\begin{array}{ll}\text { On deviants and dogs } & 147\end{array}$

Libya's transgressions $\quad 148$

Foreign demands and objectives $\quad 158$

International responses to Libya's deviance 159

Libya's responses to outside pressure $\quad 164$

$\begin{array}{ll}\text { Conclusion } & 166\end{array}$

8 North Korea 168

$\begin{array}{ll}\text { Leaders great and dear } & 168\end{array}$

Naming the deviants $\quad 174$

The DPRK's contraventions $\quad 175$

Foreign demands and objectives 189

International responses to North Korean deviance 190

North Korea's reactions to outside pressure 194

$\begin{array}{ll}\text { Conclusion } & 197\end{array}$

9 Cuba 199

From clientelism to defiance 199

Naming the deviants 205

Cuba's transgressions 206

Foreign demands and objectives 213

Foreign reactions to Cuba's deviance 216

Cuban responses to foreign pressure $\quad 222$

$\begin{array}{ll}\text { Conclusion } & 224\end{array}$ 
The road to internal turmoil and international diversity 226

Deviants and darlings $\quad 233$

Myanmar's transgressions $\quad 234$

External demands and objectives $\quad 239$

International responses to Myanmar's errant behaviour 241

Rangoon's responses to international pressure 250

Conclusion 253

11 Yugoslavia 254

A doomed state $\quad 254$

Yugoslavia III: leaner and meaner $\quad 257$

Naming and shaming the deviants 260

Yugoslavia's contraventions $\quad 261$

External demands and objectives $\quad 265$

International measures against Yugoslavia $\quad 268$

Yugoslavia's response's to foreign pressure 275

$\begin{array}{ll}\text { Conclusion } & 278\end{array}$

12 Additional African states 279

$\begin{array}{ll}\text { Nigeria } & 279\end{array}$

Rwanda $\quad 284$

Sudan $\quad 292$

Conclusion 302

13 Some Other Deviant States 303

Afghanistan 303

China 311

$\begin{array}{ll}\text { Syria } & 319\end{array}$

$\begin{array}{ll}\text { Conclusion } & 327\end{array}$

14 Non-State Deviants 328

Terrorist organizations $\quad 328$

Rebel movements $\quad 334$

'Blood' diamonds 338

$\begin{array}{ll}\text { Mercenaries } & 341\end{array}$

Transnational criminal organizations 348

Conclusion 350

Conclusion 351

Notes $\quad 361$

Index $\quad 434$ 


\section{Acknowledgements}

Many debts were incurred in researching and writing this book It is a pleasure to acknowledge them.

Thanks to a travel fellowship from the Ernest Oppenheimer Memorial Trust I was able to undertake research visits abroad. At my alma mater, Cambridge University, I could again enjoy the benefits of life membership of Clare Hall. In Havana I had the privilege of using the Centre for the Study of Africa and the Middle East as research base. At Cornell University the Peace Studies Programme again hosted me. It was at Cornell that Professor Peter Katzenstein steered me towards a critical course correction in the early stages of the research. The generosity of the Alexander von Humboldt Foundation enabled me to pay three visits to the Arnold Bergstraesser Institute in Freiburg, where Dr Heribert Weiland ensured an environment highly congenial to the lone ranger task of writing up. On a visit to Taiwan I could use the splendid research facilities of the Institute of International Relations.

Professor James Barber of Cambridge University and two anonymous readers offered insightful comments on the manuscript.

My research pursuits would not have been possible without the Rand Afrikaans University providing the opportunity. The management of the University not only preaches academic research, but actively supports the practitioners.

At the RAU Ester Ferreira of the university library handled my numerous queries with her usual combination of skill and speed; our departmental secretary Margriet Snyman tidied up the manuscript, unfazed by the tyranny of footnotes; and student assistants Willie Venter and Siobhan Neveling smartly surfed the internet to ply me with material.

My final debt, to my family, is as always the largest: Zelda, Niel and Carl had to bear the brunt of my lengthy bouts of socially deviant behaviour as I tried to make sense of deviant conduct in world politics. In her capacity as a university librarian Zelda carried the additional burden of helping me collect information for this study.

Deon Geldenhuys 


\section{Introduction}

This is not another '9-11' book, nor a post-mortem on Saddam Hussein's rule. The study began before the terrorist spectacular of 11 September 2001 - widely blamed on Osama bin Laden's al-Qaeda organization - and would have continued regardless of the attacks on the US. Likewise, Iraq would have featured as a case study irrespective of the war that toppled Saddam in April 2003. These two dramatic events have nonetheless focused international attention on the ongoing problem of delinquent conduct in world politics. The present inquiry is informed by the fact that such behaviour extends far beyond the actions of any single organization or state, however abhorrent.

The kamikaze attacks on New York and Washington have taken terrorism to an unprecedented level of death and devastation. The destructive power at the disposal of a non-state organization has been highlighted as never before: the target whose vulnerability was so starkly exposed, was none other than today's sole superpower. The world now knows for sure that seriously offensive behaviour in the realm of high politics - directly threatening the peace and security of countries - can no longer be associated with fellow-states only; it can also emanate from non-state actors, especially terrorist organizations. It is then only logical that al-Qaeda gained overnight notoriety in large parts of the world and bin Laden became America's - and indeed the wider Western world's - most wanted person in the wake of 11 September. Although US security agencies had earlier identified him as a dangerous terrorist suspect and put a $\$ 5$ million reward on his head, the attacks on the US catapulted bin Laden to the status of a true international outlaw. The terrorist chieftain became even more of an international villain than the leaders of, say, Iraq or North Korea.

The events of 11 September 2001 occurred at a time when the US was heavily preoccupied with what American policymakers labelled rogue countries. These were regarded as a new class of states bent on challenging what the US considered some fundamental, universal norms of behaviour: they were accused of pursuing weapons of mass destruction, supporting international terrorism, and committing aggression in their neighbourhoods. Such actions, Washington feared, posed a threat to international security. Iraq, among the principal rogues identified by the Americans, eventually paid heavily for its alleged misdeeds when US forces invaded and occupied the country to impose wholesale regime change.

Although the term rogue state is of recent origin, there have all along been countries breaking widely accepted standards of behaviour applicable at the time. The present study takes a broad look at what will be called 
deviant behaviour in world politics. The phenomenon will be traced back several decades, but the focus will be on rule-violating conduct by states in the post-Cold War era. Countries characterized as rogues will form a central part of the investigation, but we will not be constrained by this paradigm. Attention will also be paid to transgressions committed by countries not on the Americans' roster of rogues. The rogue state paradigm, it will be argued, is also sorely deficient in that it emphasized particular aspects of the external conduct of errant states, while ignoring several other forms of rulebreaking behaviour that also merit critical attention. And as the rogue state designation furthermore implies, it is confined to the offensive behaviour of states only. We have already suggested that non-state actors need to feature in a study of deviant conduct in world politics; they too influence the process of 'who gets what, when, how'. In practice, state and non-state deviants are not travelling in separate orbits, so to speak, but may be closely connected. Symbiotic relations do, for instance, exist between some states and terrorist organizations or crime syndicates.

It must already be apparent that a critical part of the inquiry is the charges of misconduct levelled against delinquent actors - both states and non-state organizations - in terms of the rules of conduct they were said to have challenged or defied. The analytical framework guiding the investigation draws on the sociology of deviance, which focuses on the violation of generally accepted behavioural standards. For our purposes these are codes of conduct enjoying wide acceptance within the world community. Other key components of the proposed framework are the responses of international actors to instances of deviant behaviour, and the ways in which deviants reacted to foreign pressures related to their errant ways. It is an analytical framework that reaches both wider and deeper than the American rogue state paradigm.

Since deviance occurs over a broad front in international affairs, a study of this nature cannot investigate every state or non-state actor displaying rule-breaking behaviour. Among the countries excluded are Saudi-Arabia under its absolute monarchy, Sierra Leone and Côte D'Ivoire under military rule at the end of the previous century; Indonesia in the dictatorial Suharto era, especially during the final stages of its brutal occupation of East Timor; Pakistan under the military rule of General Pervez Musharaff since October 1999; several former Soviet republics - including Azerbaijan, Uzbekistan and Kyrgyzstan - where human rights were being systematically abused, and Zimbabwe in the grip of authoritarianism since the late 1990s. The chosen case studies nonetheless represent a wide range of contemporary states, including both designated rogue countries and others not on the US blacklist. Due to space constraints not all cases are examined in equal detail; some are 'mini' case studies. The cut-off date of the inquiry is the first half of 2003. 